\title{
Some impressions of genitourinary medicine in Buenos Aires, Argentina
}

\author{
I ANNE TAIT \\ From the University Department of Genitourinary Medicine, Royal Liverpool Hospital, Liverpool
}

When my husband was invited to the Fourth International Conference on Electrostatic Accelerator Technology and Associated Boosters in Buenos Aires from 15 to 19 April 1985 it seemed too good an opportunity to miss. I wanted to meet doctors there and wrote to Dr Duncan Catterall, Vicepresident of the International Union of Venereal Diseases and Treponematoses (IUVDT), who kindly introduced me to Dr Zacarias, epidemiologist with the Pan American Health Organisation (World Health Organisation). As a result, I arrived in Argentina with letters of welcome from Dr Ambrona, past president of the Latin American Union against Sexually Transmitted Disease, and Dr Stamboulian, President of the Pan American Infectious Diseases Association. The Buenos Aires telephone system is described as "chaotic"; and I was grateful to the staff of the conference secretariat who managed to contact these doctors only after repeated efforts over 48 hours.

As information about sexually transmitted diseases (STD) from Argentina and indeed from the whole of South America is very scanty or non-existent, I thought it would be of interest if I wrote a personal account of what I saw and heard during a very brief visit to hospitals and clinics. Clearly my observations must be very superficial despite the great efforts of my hosts to reveal the full picture as they saw it.

The population of Argentina is 30.2 million and of Buenos Aires is 3.5 million ( 9 million in Greater Buenos Aires). Seventy five per cent of Argentinians are urban dwellers. Such centralisation, which was encouraged in the past, has had a very deleterious effect on the economy. During our visit the inflation rate in Argentina was about $1 \%$ a day. Salaries were reviewed once a month, and the inadequacy of these reviews caused a strike of university staff in mid-April and other unrest has followed.

Regarding the Falklands war, though our visas arrived only on the morning of our departure and we had to travel via Paris, once we were in Buenos Aires we detected no animosity. Graffiti were widespread, but I only saw two items referring to the Malvinas and the British in derogatory terms. From time to time

Address for reprints: Dr I Anne Tait, University Department of Genitourinary Medicine, Royal Liverpool Hospital, Prescot Street, Liverpool L7 8XP

Accepted for publication 21 July 1985 with other conference wives I travelled on the "collectivos", single conductor/driver city buses and had problems with our destination and fares, but adolescents speaking good English would regularly appear and befriend us. In Buenos Aires politics and economics replace the weather as a prime topic of conversation, and "the 1982 conflict" was unanimously dismissed as a politicians' mistake as a result of which the Argentinians had changed their president for the better. It may be that had we been there for any relevant anniversary, attitudes would have been less relaxed.

Dr Stamboulian had invited me to a seminar on "Hospital infections with Gram negative bacilli" in the headquarters of the Armenian Cultural Association, in a suburb where many Armenian immigrants have settled. The special guest was $\mathrm{Dr}$ Stuart Levin from Rush University, Chicago, a specialist in preventive medicine. Simultaneous Anglo/Spanish translation was provided but, having a faulty apparatus, I found that Spanish medical terms were reasonably comprehensible and it became obvious that the tenor of the discussion concerned the relatively reduced availability of antibiotics in Argentina compared with the United States. Regarding pelvic inflammatory disease, chemotherapy was based on the assumption that, as in North America, Neisseria gonorrhoeae was still the primary pathogen. (The sponsors, Ciba-Geigy, were demonstrating a computer based reference search facility that they proposed to instal and maintain in şeveral city hospitals.)

Next morning, Dr Stamboulian's secretary escorted me to his department of infectious diseases in the Guemes Sanatorium, a modern private hospital of 1000 beds where 40000 outpatients are seen yearly and 80 to 100 operations carried out in 30 theatres daily. Adequate social security payments are a prerequisite for attendance at this hospital, which is owned by a syndicate of local business men. Junior hospital doctors (salary US $\$ 200$ a month) are not paid at an appropriate level. An exception is made in acute cardiac surgery (both adult and paediatric) for which a charitable foundation exists.

The department of infectious diseases sees patients with STD only on referral from other consultants and is responsible for the control of hospital infections in 
general. A national programme of infectious disease control and education is being implemented. Dr Stamboulian's young trained staff are appointed to consultant posts in the hinterland to encourage decentralisation.

Dr Stamboulian and about 20 junior doctors from various disciplines invited me to talk about our work in Liverpool (Dr Stamboulian translating). Searching questions followed, from which I learned much - in particular how limited their microbiological back-up service was, notably in tissue culture facilities for diagnosing chlamydial infection and genital herpes. For example, a provincial outbreak of chancroid was being investigated without the possibility of excluding herpes simplex virus. Research into chlamydial infection using monoclonal antibody techniques has, however, started.

Later Dr Stamboulian's junior "fellows" showed me all over the multistorey hospital from the prestigious cardiac surgery and intensive care units to the bacteriology department in the basement, where first class laboratory standards would be difficult to maintain due to a lack of modern equipment. A new department in the course of construction was pointed out to me as we went to lunch in the local cafe.

There they talked of the medical training system in Buenos Aires. About 2000 doctors (far more than are needed) graduate each year from a first year intake many times that number. This includes many students from other Latin American countries where a means test enforces payment for tuition, which is free in Buenos Aires. Postgraduate examinations are organised by the Medical Academy of Buenos Aires (mainly a research establishment, where some of the 26 Argentinian cases of the acquired immune deficiency syndrome (AIDS) are being investigated). They envied our Royal College system despite the low percentage pass rate, and hoped for attachments abroad before settling down in Argentina.

The following day Dr Ambrona took me to the University Hospital. In contrast to the Guemes Sanatorium, this is a free hospital with unrestricted access, though the antibiotics prescribed are sometimes not available. There is a small prescription charge except in the venereology department. Though the latter serves both sexes, many women are investigated in conjunction with the gynaecology department, which adjoins it. (Provision for sailors was freely available in Port Medical Authority clinics, which I did not visit). Both clinics were very busy and extremely congested. Patients were seen from 8 am onwards. Secretaries and laboratory technicians took the histories and carried out routine tests and when the doctor arrived the results were available and treatment was given.

With Dr Luis Belli, the dermatovenereologist in charge of that clinic, and Dr Itala, head of the gynaeology department, and later over lunch with Dr Ambrona, I discussed many aspects of medicine in Argentina. Though the official Argentinian figures for 1979-80 (the latest available) report 40 new cases of syphilis and only 60 of gonorrhoea per 100000 population, under-reporting was acknowledged to be widespread and it has been estimated that in 1984 in Argentina there may have been as many as 100000 cases of syphilis (but no pinta of yaws) and 250000 cases of "genital discharge" including gonorrhoea. In Buenos Aires, however, because of recently enforced rigorous testing of pregnant women, there were only 10 cases of congenital syphilis in 1984. Non-gonococcal urethritis (NGU) was thought to be only two thirds as common as gonorrhoea, though again the shortage of diagnostic facilities was deplored. Prepubescent cases of gonococcal vulvovaginitis were widespread in children's hospitals, but the prevalence of neonatal conjunctivitis was unknown as Credé's method of prophylaxis was universal.

Cases of gonorrhoea due to ß-lactamase producing strains were not believed to "exceed 5\%, and spectinomycin was banned because of its ototoxic effects. Benzathine penicillin to a maximum of four injections was used to treat syphilis, though $\mathrm{Dr}$ Ambrona had investigated alternative methods of syphilotherapy. Genital herpes showed the greatest increase in incidence, but acyclovir was not available. A trial of interferon ointment (from Israel) in the treatment of cervical warts and dysplasia was in progress. As elsewhere in Latin America, the incidence of cervical cancer was said to be high, equalling that of breast cancer. Various treatments of vaginitis caused by Gardnerella spp, including amoxycillin, metronidazole, triple sulpha cream, and amphotericin, were under investigation.

Prostitutes, though obvious on the streets and classified by Dr Ambrona at all social levels, are said to contribute only $4 \%$ of STD infections in men, much less than in the northern Latin American countries. Legally, they do not exist and are not controlled, unlike girls in bars or massage parlours, establishments recently mushrooming in Buenos Aires.

I thank Dr Ambrona and Dr Stamboulian for their generosity in giving me so much of their time and knowledge. The junior doctors in Argentina look abroad for their higher medical training, and their senior colleagues made it clear that they would like stronger links with Britain. The Argentinian economy is in a parlous state, and it would be a gesture of friendship if funds could be made available for a place on one of the British postgraduate courses in venereology.

The information in the above article was supplied to me by many different sources, but the opinions, conclusions, and any misinterpretations are entirely my responsibility. 